\title{
Evaluating Knowledge Transfer Policies and Practices: Conceptual Framework and Metrics
}

\author{
ANTHONY ARUNDELANDSACHA WUNSCH-VINCENT
}

\subsection{Introduction}

As outlined in Chapter 1, a common policy goal in both high- and middleincome countries is to increase the commercialization of research findings produced by the public research sector in order to support economic growth. This process involves the transfer of knowledge produced by public research organizations, including both universities and public research institutes, to private sector businesses or government agencies.

A diverse range of policies have been implemented in many countries to encourage knowledge transfer, including the establishment of knowledge transfer offices (KTOs) ${ }^{1}$ at universities and public research institutes. Other policies include support for open publication and close collaboration between universities/public research institutes and businesses. One important issue is how to evaluate the success of these policies in terms of their economic impacts and their effect on various actors within an innovation system. Possible evaluation methods include case studies and the collection and analysis of knowledge transfer metrics. The latter have often involved the use of IP licensing data.

IP licensing is only one of several channels for transferring knowledge produced by universities and public research institutes to private firms. However, it is an important focus for research on knowledge transfer, both in the research reported in this book and in the academic literature. The research focus on IP licensing partly reflects its importance to knowledge transfer policies in developed countries, as described in Chapter 1, and partly reflects the widespread

${ }^{1}$ KTOs were originally known as "technology transfer offices," or TTOs. The use of "TTO" has fallen out of favor because transferred knowledge can be nontechnological, such as the rights to biological tissue or software programs. 
availability of relevant data, in contrast to a lack of data for other knowledge transfer channels.

This chapter provides a conceptual framework for the country case studies included in this book, and identifies the most commonly used metrics for knowledge transfer mediated by the licensing of IP. It describes different methods of knowledge transfer, policies and practices for supporting knowledge transfer (particularly via IP), and the costs and benefits of IP licensing. One key message from the chapter is that reliance on IP metrics may underestimate the extent of knowledge transfer in the economy and that informal methods of transfer may be a precursor to more formal relationships.

\subsection{Channels of Knowledge Transfer}

The public research sector has three main roles that are supported by government policy. The first is to create trained and educated citizens, the second is to push the frontiers of knowledge by undertaking cutting edge research, and the third is to support economic activity through several channels for transferring knowledge from universities and public research institutes to the business sector (see Figure 2.1). In recent years this third role of knowledge transfer is becoming increasingly important and is often referred to as the "third mission" of universities. Economically useful knowledge can also be transferred to government and nonprofit organizations. The transfer of knowledge to government often occurs through the procurement of research services, with the goal of improving public services or addressing social needs.

Knowledge transfer occurs through both informal and formal channels. Informal channels include reading the literature, attending conferences, hiring trained graduates, ${ }^{2}$ and discussions via personal contacts. These have also been combined under the rubric of "open science" because they make knowledge publicly available at little or no cost (Cohen et al. 2002). Formal channels include licensing, collaboration and research agreements, and contracting-out. In general, informal channels do not require the recipient of the knowledge to make a payment to the institution via a contract, whereas formal channels use a contract to mediate payment. Knowledge can be transferred entirely through informal channels, entirely through

${ }^{2}$ See Foray and Lissoni (2010). Hiring university graduates is one of the most important channels from the perspective of businesses, but is arguably not a formal channel because it does not require a contract with a university. Conversely, hiring academics for a limited period of time, such as in a personnel exchange, requires a contract between a business and a university. 


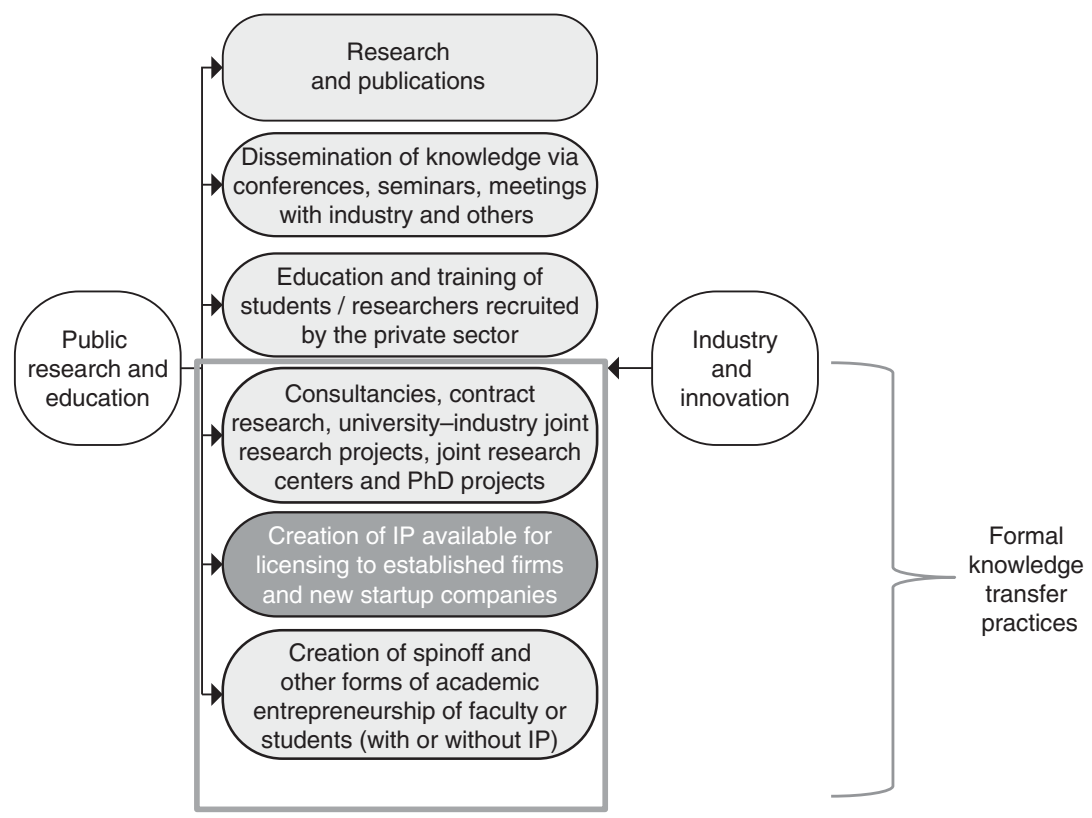

Figure 2.1 Knowledge transfer channels between the public research sector and businesses

Source: WIPO (2011)

formal channels, or through a combination of both, for instance, when informal discussions lead to a research agreement that results in an IP license.

It is important to place knowledge flows from public research to firms in context. They play only a minor role in the flow of knowledge within an innovation system. A 2010 survey of manufacturing firms in the United States of America (U.S.) found that 49 percent of firms obtained the invention behind their most important innovation from external sources, attesting to the importance of knowledge flows to an innovation system, but only 10 percent of them reported that this invention was from a university. Importantly, however, inventions obtained from technology specialists, including universities, were of higher value than inventions obtained from other sources such as customers or suppliers and 37 percent of inventions obtained from technology specialists were based on a formal channel (Arora et al. 2016). ${ }^{3}$

3 The authors do not break down the use of formal channels within the category of technology specialists, which includes universities, independent inventors, and consultants/service providers. 
A consistent issue, identified in multiple studies, is the dependence of knowledge transfer on the ability of firms, particularly firms in the region where the university or public research institute is located, to absorb or use inventions produced by public research. Research shows that knowledge transfer activities increase with the technological capabilities of domestic or regional firms (Van Looy et al. 2011; Curi et al. 2012; HewittDundas 2012; Calderón-Martínez and García-Quevedo 2013; Okamuro and Nishimura 2013; Hussain et al. 2014; Ranga et al. 2016). This is an important issue in low- and middle-income countries and for regional institutions in developed countries, where firms may lack sufficient absorptive capacity (see Chapter 10). In addition to regional differences, firms that rely on informal personal contacts are smaller and have lower levels of absorptive capacity than firms that use formal knowledge transfer methods (Freitas et al. 2013).

Not surprisingly, firm involvement in knowledge transfer from public research organizations increases with the firm's R\&D intensity (Freitas et al. 2013; Okamuro and Nishimura 2013; Kafouros et al. 2015). One study also finds that firm involvement with universities increases with the number of universities in a region, possibly because it increases the probability of a good match between the needs of firms and what universities can offer, or because greater competition between universities increases the flexibility of academic and KTO staff (Okamuro and Nishimura 2013).

Albuquerque et al. (2015) describe an international survey on the use of different knowledge channels by firms in low and middle-income countries in Africa, Asia and Latin America. In two low-income countries (Nigeria and Uganda) informal methods dominate (Kruss et al. 2015), whereas in middle-income countries in Asia (China, Malaysia, and Thailand) the most common methods are consultancy and research contracts (Schiller and Lee 2015). One explanation for the importance of contractual relationships in Asia is their usefulness in building innovative capacity and problem-solving abilities in firms. In four middle-income Latin American countries (Argentina, Brazil, Costa Rica, and Mexico), both contracts and informal channels are used more frequently than IPmediated methods (Dutrénit and Arza 2015).

From a public policy perspective, providing information to businesses at no cost via informal channels will be beneficial if it increases the number of businesses that use the information to develop commercial products and processes. In addition, competition will reduce costs for 
consumers. The exception is when no business will invest in commercializing knowledge without an exclusive license, for instance, when the cost of commercializing knowledge is high but the cost for competitors to copy it is low. In this case, public research institutes and universities need to be able to provide firms with exclusive licenses to IP-protected knowledge.

One of the main purposes of the 1980 Bayh-Dole Act in the U.S. was to allow public research organization to provide exclusive licenses. The Act also led to widespread adoption of the "IP licensing model" for knowledge transfer, defined in this book as the use of IP to mediate the transfer of knowledge. The IP licensing model has been widely used, even when IP is not required for firms to develop and commercialize knowledge, as when an exclusive license is not given. This is partly because universities and public research institutes were attracted by the potential income from both nonexclusive and exclusive licenses, as well as the need to recover the costs of maintaining a KTO. In addition, the IP licensing model can have other benefits, such as signaling the existence of inventions to firms.

Importantly, policies or research that account for only one type of linkage can provide only a partial understanding of the patterns of interaction between the public research sector and businesses. Nevertheless, the focus of this conceptual framework is on knowledge transfer systems that involve, at some point, formal transfer methods, while recognizing that many formal methods will originate in informal relationships between university researchers and private businesses.

\subsection{The Role of Policies and Practices in Promoting Knowledge Transfer}

Policies to support knowledge transfer between public research institutes and universities and firms should be designed to support multiple knowledge channels and should take into consideration the advantages and disadvantages of each channel and the suitability of different types of knowledge for specific channels. The role of KTOs has adapted over time to take these issues into account, with a greater recognition of the need for KTOs to support informal channels (for instance by arranging "meet and greet" events between academics and business), in addition to their traditional role in supporting the IP licensing model. 
Universities and public research institutes can also create a supportive environment for knowledge transfer through secondary activities such as educational programs to teach entrepreneurship to students and faculty and by creating innovation incubators and science parks (Rothaermel et al. 2007). Incubators and science parks can attract businesses to conduct some of their activities close to the university and encourage contacts with researchers and entrepreneurial students and staff.

Relevant policies and practices to support knowledge transfer occur at both the national and institutional level.

A review of existing policy research to date reveals a few important lessons (WIPO 2011). First, despite the general trend toward institutional ownership and commercialization of university/public research institute inventions, a diversity of legal and policy approaches persists in terms both of how legislation is anchored in broader innovation policy and of the specific rules on the scope of patenting, invention disclosure, incentives for researchers (such as royalty sharing), and whether safeguards are instituted to counteract the potentially negative effects of patenting. Second, there is a large variation in the means of implementing such legislation, as well as the available complementary policies to enhance the impact of public $\mathrm{R} \& \mathrm{D}$ and to promote academic entrepreneurship.

\subsubsection{National and Institutional Policies and Practices to Support Knowledge Transfer}

The most common national policy of direct relevance to knowledge transfer concerns the ownership of IP developed in the public research sector. In some countries, such as the U.S., national laws give ownership to the institution, other countries, Sweden, for instance, assign ownership to the inventor, while yet others, such as Canada, leave the decision to the institution.

An extensive literature exists on the factors that are linked to successful knowledge transfer by KTOs, but there is only limited research on the effect of institutional practices at the level of the university or public research institute (Barjak et al. 2015; Belenzon and Schankerman 2009). Relevant practices include:

- activities to create an institutional culture that supports knowledge transfer; 
- the establishment of institutional strategies for knowledge transfer and commercialization, such as rules for transparency in contract negotiations;

- incentives for staff to disclose inventions and support knowledge transfer by working with potential licensees;

- policies that encourage academic startups, such as allowing faculty to create and own a share in a startup or to take a leave of absence, the provision of finance, and supportive infrastructure such as incubators and science parks.

Overall, the evidence stresses the importance of a well-defined IP policy. Universities with internal rules supporting the participation of researchers in knowledge transfer perform better than universities without such rules (Debackere and Veugelers 2005). Further discussion of the effect of institutional policies on knowledge transfer is provided in Chapter 10.

\subsection{Costs and Benefits of the IP Licensing Model}

Since knowledge transfer can occur through multiple channels, an important policy goal is to ensure that the IP licensing model will drive knowledge transfer and business innovation while at the same time preserving open science (Foray and Lissoni 2010) and the benefits of other contractual or informal channels for knowledge transfer (Rosli and Rossi 2014; Veugelers 2016). ${ }^{4}$ Combining informal and formal channels can have a positive effect on innovation outcomes (Siegel et al. 2003; Link et al. 2007; Grimpe and Hussinger 2013). The use of both channels could be especially important to spinoffs (Hayer 2016).

Maintaining multiple channels and supporting positive synergies among them depends on maximizing the advantages and minimizing the disadvantages of existing and potential policy approaches. Effective outcomes also depend on the specific details of IP policy implementation at the national, regional and institutional levels.

The potential costs and benefits of the IP licensing model, as discussed in the literature, are summarized in Tables 2.1 and 2.2. Table 2.1 distinguishes between possible benefits and costs for the two respective main

${ }^{4}$ Czarnitzki et al. (2016) find that the change in Germany from professor's privilege (academics may own the IP) to institutional ownership did not result in an increase in new startups, possibly because the new policy interfered with the previous knowledge transfer system that was based on academic-firm interactions. 
Table 2.1 Impacts of IP-based knowledge transfer policies on universities/ public research institutes and firms

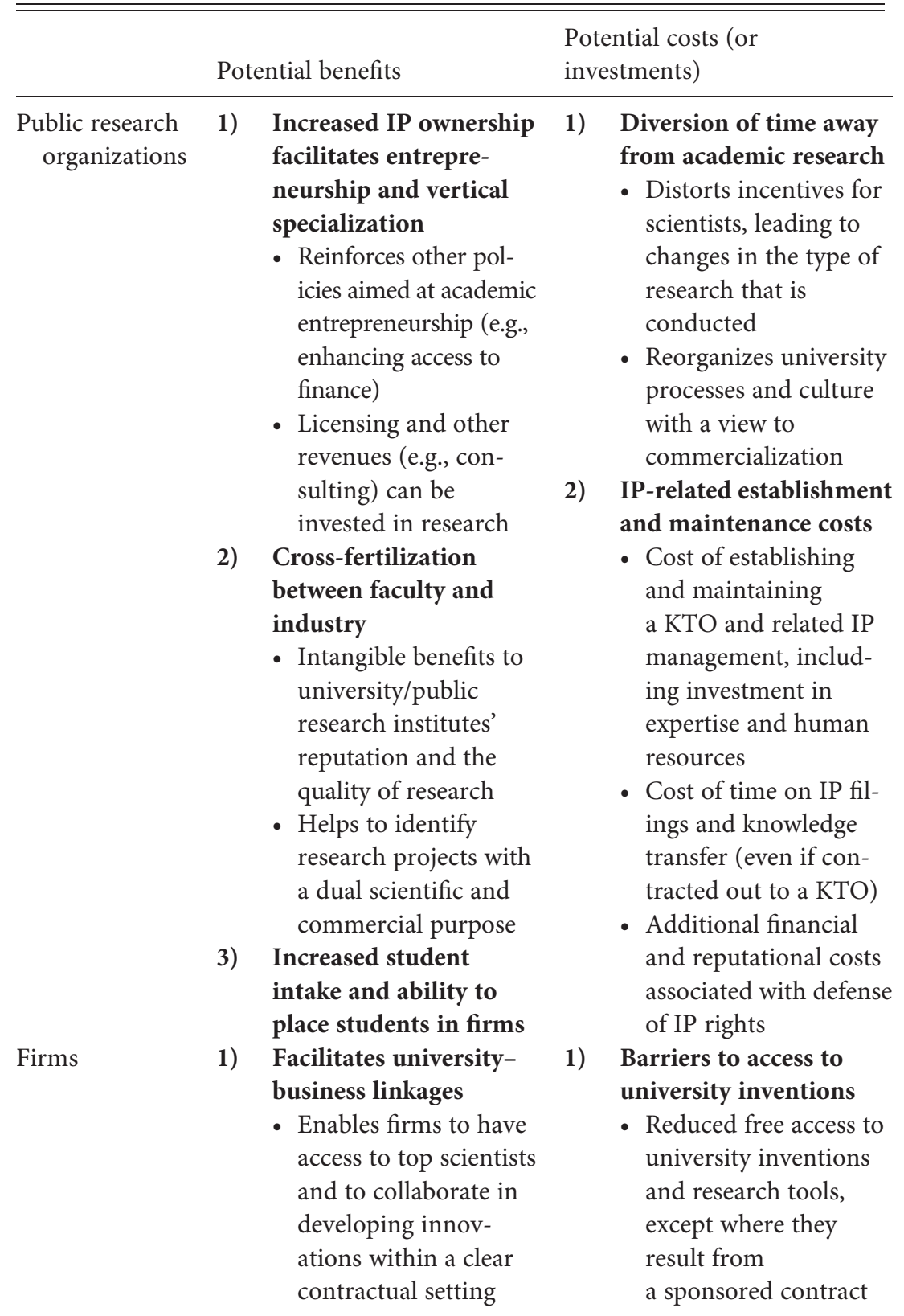


Table 2.1 (cont.)

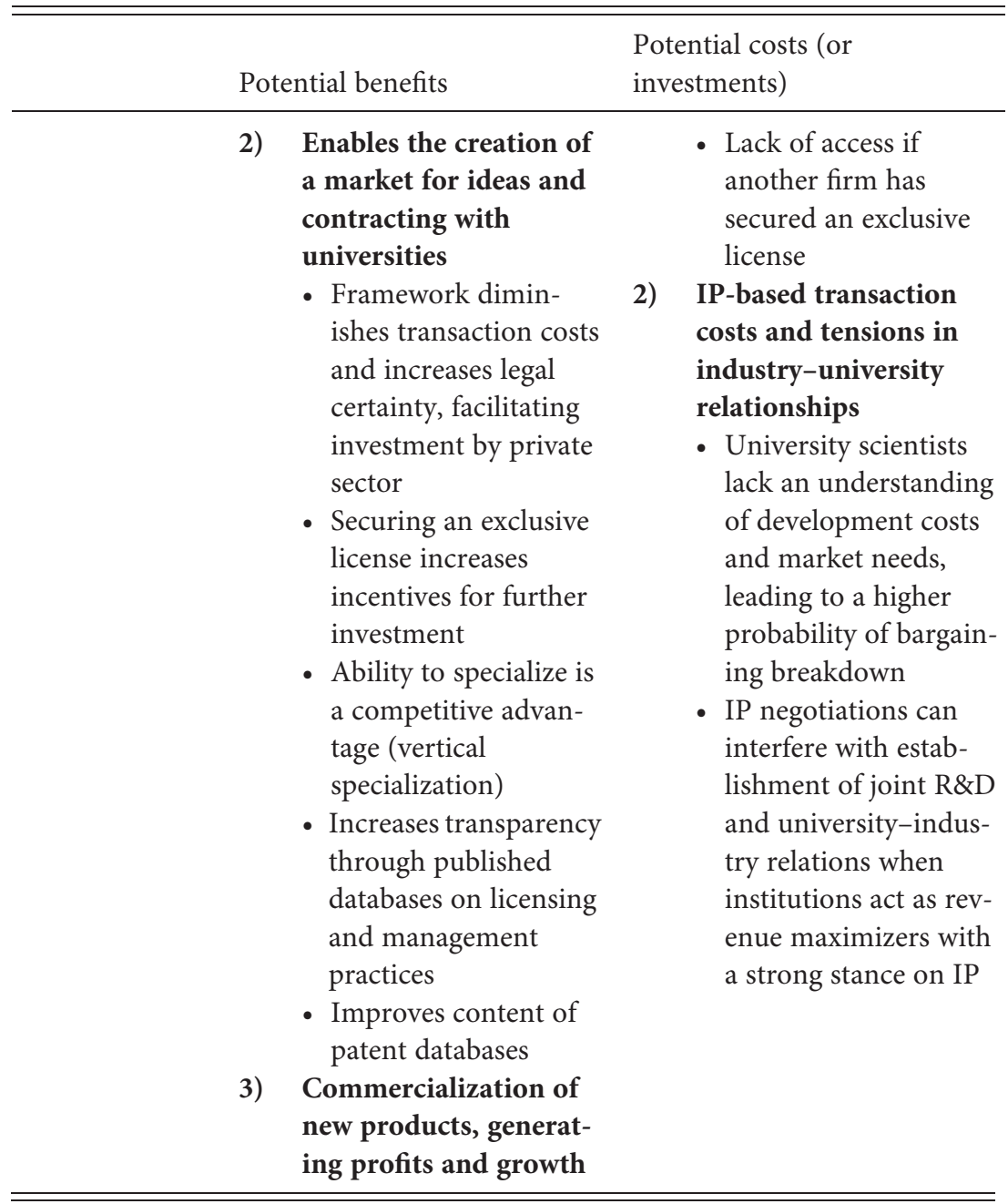

Source: Authors

agents (firms and public research organizations), while Table 2.2 summarizes the systemic impacts of IP licensing on science, the economy, and society. Table 2.3 adds additional notes of relevance to middleincome countries (WIPO 2011; Zuñiga 2011). 
Table 2.2 Socioeconomic effects of IP-based knowledge transfer policies

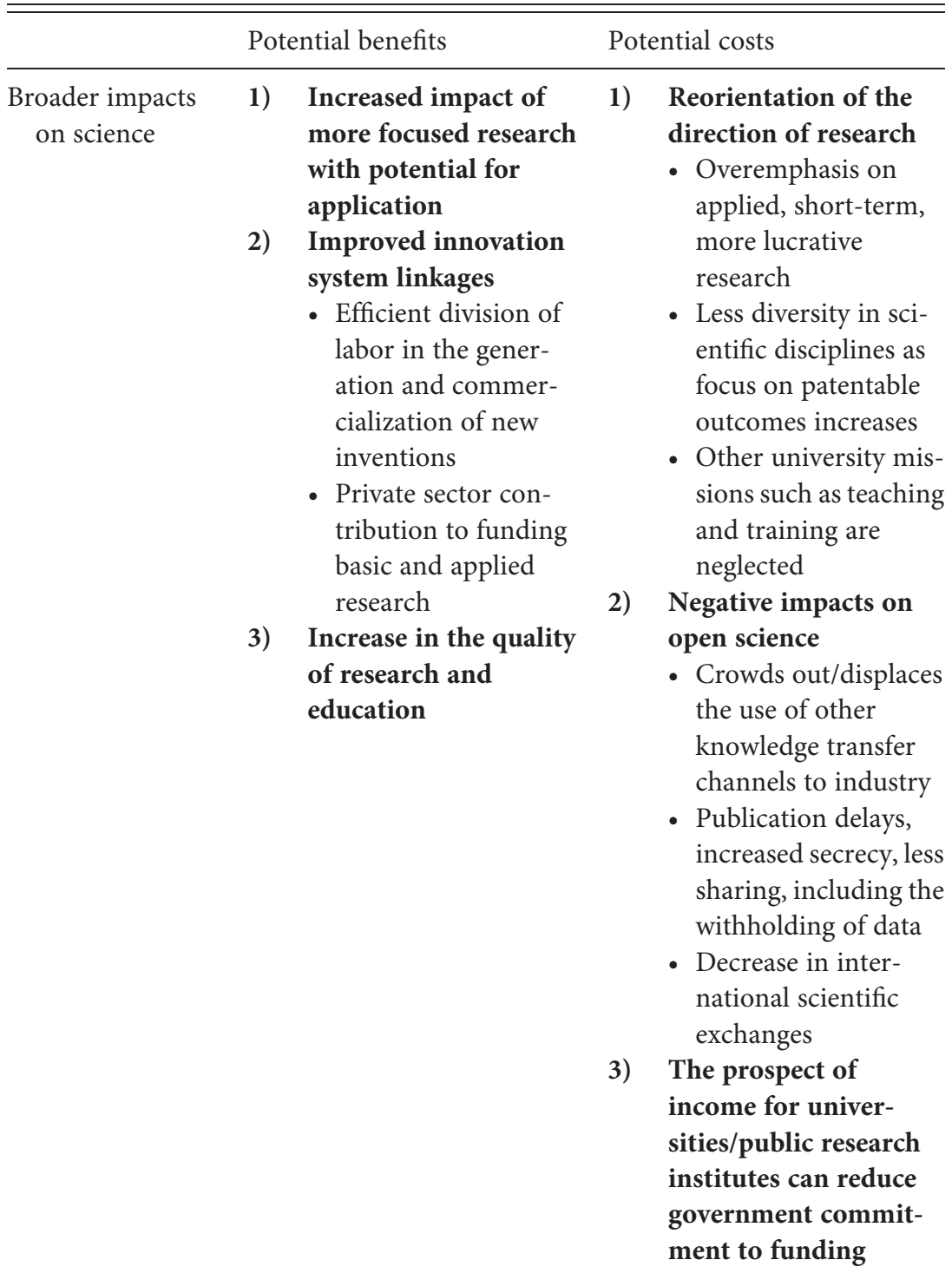


Table 2.2 (cont.)

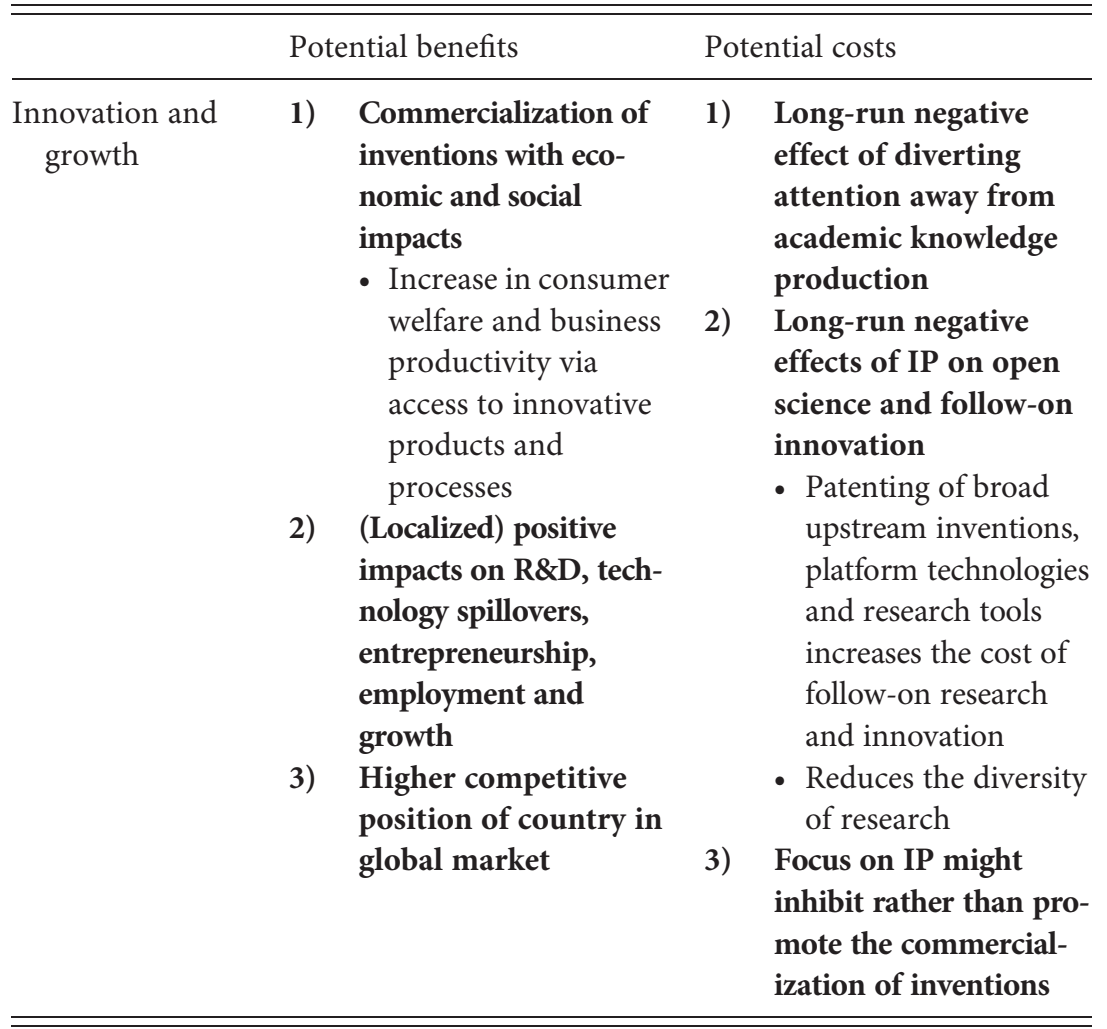

Source: Authors

\subsubsection{Advantages}

Due to data availability (discussed in section 4), we know more about the IP licensing model in high- and middle-income countries than other forms of knowledge transfer. Patents are the classic form of IP, but IP is also used to protect plant varieties (plant breeders' rights), biological tissue, knowhow (protected under secrecy), industrial designs, and copyright (relevant to software outside the U.S.). ${ }^{5}$

Studies show that the IP licensing model has supported the emergence of new industries, such as the scientific instruments industry, semiconductors, computer software, and the nano- and biotechnology industries (Rosenberg

5 Trademarks constitute another form of IP, but are rarely licensed by universities or public research institutes. 
Table 2.3 Impacts on low-and middle-income countries

Potential benefits

1) All the benefits mentioned above (see Tables 2.1 and 2.2)

This depends, however, on the capacity of businesses to absorb and further develop university inventions - either by domestic firms or by locally present multinational firms - and whether or not these inventions are relevant to the needs of low- and middleincome countries

2) Ability to contribute to local or global markets for university inventions

This depends on the capacity to generate university inventions and file patents

University inventions might also attract the presence of multinational companies and their associated complementary R\&D

Strengthened science-industry links could help reorient research toward local needs

3) Improved visibility of public research inventions

Local firms may find it easier to identify relevant inventions and academics through patent searches than through searches of academic literature
Potential costs

1) All the above-mentioned costs (see Tables 2.1 and 2.2), some of which are amplified given the greater resource constraints of less-developed economies

- Reduced or no access to critical technologies owned by universities in high-income countries

- Overemphasis on applied, lucrative projects may lead to less useful inventions from the point of view of low- and middle-income countries

- The decrease in international scientific exchanges and a reduced willingness of institutions in highincome countries to collaborate as a result of more complex IP ownership issues and secrecy

- High cost of obtaining international patent protection for university inventions and resulting opportunity costs

Source: Authors

and Nelson 1994; Zucker et al. 1998; Di Gregorio and Shane 2003). Startups based on university/public research institute IP are also more likely than established firms to commercialize new technologies that are radical, early stage, or of a general-purpose nature. However, attributing these positive impacts exclusively to the IP licensing model is difficult in the absence of research on the role of other knowledge transfer channels. 
The IP licensing model has secondary benefits other than its primary objective of transferring a specific set of knowledge to one or more businesses. These other benefits depend on the ability of a patent to signal the presence of expertise within a university/public research institute via the information contained in it, which can lead to mutually beneficial collaborative and contract research agreements, placements for graduate students, funded $\mathrm{PhD}$ scholarships and improvements in research quality. The cross-fertilization of ideas, problems, and knowledge between universities/public research institutes and firms can facilitate joint problem solving and open up new avenues for research (Owen-Smith and Powell 2003; Azoulay et al. 2009). While this has been an ongoing trend in high-income economies over the last few decades, it has enormous potential benefits for low- and middle-income economies, particularly in building up the research capabilities of universities.

Many of the secondary benefits extend beyond unidirectional knowledge exchanges between universities or public research institutes and firms. Industrial research can complement and guide the direction of basic research. Contractual arrangements with firms can provide university scientists with funds to purchase advanced equipment and instruments.

The signaling function can also be met through publication in scientific and technical journals, but the focus of patents on inventions with commercial possibilities could have an advantage over publications, where commercial ideas could be more time-consuming (and therefore costly) for businesses to identify. Furthermore, the existence of patents signals the willingness of the institution to license knowledge.

\subsubsection{Disadvantages}

Open science is based on the norms of rapid disclosure of research results and an environment of knowledge sharing, co-authorship and joint projects that contribute to cumulative learning. The patenting of university inventions could have negative effects on these norms by slowing the diffusion of university inventions, including research tools. This could have an unintended effect of stifling private sector innovation (Eisenberg 1989; Heller and Eisenberg 1998; Kenney and Patton 2011). ${ }^{6}$ In particular, the exclusive licensing of patents to single firms could limit the

${ }^{6}$ Kenney and Patton (2011) note that the institutional arrangements within which KTOs are embedded have encouraged some of them to become revenue maximizers rather than facilitators of technology dissemination. 
diffusion of knowledge generated with public funds, reducing the diversity and number of follow-on innovations.

Moreover, strong IP policies could negatively affect other knowledge transfer channels that might be equally or more effective in supporting knowledge transfer under specific conditions. These include informal knowledge exchanges between businesses and academics as well as formal R\&D collaboration, which could be affected by the need for complex negotiations over IP rights.

The nonfinancial disadvantages of close university-industry linkages include a loss of academic freedom, a decline in basic research, ${ }^{7}$ a shift away from research of low commercial interest, and restrictions on or delays in publication due to the interest of commercial partners in secrecy (Van Looy et al. 2004; Tartari and Breschi 2012; Muscio and Pozzali 2013). Examples have been noted of companies restricting the findings of university researchers or researchers denying others access to their data (Campbell et al. 2000; Campbell et al. 2002). Despite these examples, none of the research to date has found strong negative effects that cannot be managed with good university codes of practice (Fabrizio and Di Minin 2008; Czarnitzki et al. 2009; Grimaldi et al. 2011).

The lack of strong evidence of negative impacts could be partly due to research designs that are unable to detect problems. For example, the importance of publication delays is likely to be greatest for early-career researchers such as $\mathrm{PhD}$ candidates and post-doctorates who need to build up a list of publications rapidly. Yet this possible effect is missed in studies that focus on heads of research groups or university departments. This could be one reason why a study of departmental heads finds that publication delays are given a low importance ranking as a barrier to collaboration with industry, whereas the choice of research ranks much higher (Muscio and Pozzali 2013).

The risk of industry exerting an undue influence on academic research is constrained by the small share of university R\&D that industry funds. ${ }^{8}$ In the U.S., for example, industry finances about 5 to 6 percent of all basic

7 Thursby and Thursby (2007) find a small decline in the number of publications in basic science journals in years in which academics disclose a discovery. This could be because disclosure creates work related to patenting and licensing that decreases the time available for basic research.

8 Official statistics show a modest but increasing share of industry-funded R\&D carried out in academia. This has increased in OECD countries from an average of 2.9 percent in 1981 to 6.6 percent in 2007. In Argentina, China, and the Russian Federation, firms also fund a stable or increasing percentage of academic $\mathrm{R} \& \mathrm{D}$. 
and applied academic R\&D, respectively, although its share (and likely influence) is much higher in health-related R\&D.

The adoption by universities of a proactive patenting strategy can create other disadvantages. Long delays in reaching an agreement over IP terms, or university actions to maximize their potential revenue (Alexy et al. 2009; Wadhwa 2011), ${ }^{9}$ can discourage university-industry collaboration. Firms can also be discouraged if institutions use a "one-size-fitsall" approach to patenting research results that ignores the evidence that patents and exclusive licensing play different roles in the development of complex versus discrete technologies (So et al. 2008).

Few studies have assessed the disadvantages of institutional IP strategies. Instead, studies show that often - and despite potential friction university IP, collaboration, and research productivity go hand in hand. Universities that collaborate more with industry also tend to have the most patents.

The IP licensing model could have negative effect on low- and mediumincome countries by raising the costs for businesses to license research tools, databases, and technologies (Boettiger and Bennett 2006; Engel 2008; So et al. 2008; Montobbio 2009). In particular, by increasing prices, stricter IP practices could hinder access to technologies in agriculture, health, and essential medicines that are of critical importance to less-developed economies (Boettiger and Bennett 2006). Another concern is that opportunities for scientific networking or collaboration between scientists in high-income and less-developed countries could be negatively affected by conflicts over university patenting strategies (Clemente 2006).

\subsubsection{Minimizing the Costs of IP-Mediated Knowledge Transfer}

Universities/public research institutes, funding agencies, donors, and governments have two levers for preventing or limiting the potentially negative impacts of IP-based knowledge transfer. First, the patenting and licensing of specific types of invention can be restricted. For instance, guidelines can demand that patents should be sought, and exclusive licenses attributed, only where they are a necessary condition for their commercialization. University policies and government bodies can also declare certain areas offlimits to university patenting: basic research, research tools, or technologies critical to public health in low-income countries.

9 Firm managers have argued that it has distanced universities from firms in the U.S. and has been one reason why US firms collaborate more with firms abroad (Litan et al. 2008). 
Second, when inventions are patented, the type of and access to downstream licenses can be influenced by legislation or institutional policies. For instance, licensees of government-funded technologies can be required to disclose follow-on investment and the steps taken to commercialize the patent. The goal is to prevent firms from using licensed patents to block follow-on inventions by other firms. Other requirements can ensure that products derived from licensed inventions are sold to consumers or poorer countries on reasonable terms (OECD 2003; So et al. 2008). Field-of-use restrictions can be implemented to ensure that the IP is made available for future research, including to other firms. Governments can also reserve the right to practice the invention or override exclusive licensing rights ("march-in rights").

Universities and public research institutes are experimenting with a number of interesting additional approaches, such as open IP policies. These include patenting and licensing strategies (e.g., granting firms nonexclusive rather than exclusive licenses, making licenses available for free or at low cost if used for humanitarian or not-for-profit purposes or by small firms or startups in selected technologies), and providing easier access to research tools and to copyrighted works such as teaching materials, an often-neglected IP issue.

\subsection{Measuring Knowledge Transfer}

Table 2.4 lists the variety of possible knowledge channels, including informal channels consisting of "open science" and two types of formal channel. There is a lack of consistency in the literature on the definition of formal channels, with some studies combining consultancy and contract research with informal methods in order to focus on the difference between IPmediated channels and all other channels (Tartari and Breschi 2012; Abreu and Grenevich 2013). The formal channels are divided into those that support the creation of new knowledge by a university or public research institutes, and contractual methods for accessing existing knowledge produced by a university/public research institute via IP licensing. Table 2.4 also identifies the main data sources on knowledge transfer for each channel.

With a few exceptions, ${ }^{10}$ surveys show that the most common channels for both firms and academics in high-income countries are open

${ }^{10}$ Shapiro (2012) finds that firm managers in Korea give low importance to informal methods such as publications and conferences. Hiring is given the highest importance, followed by patents and contracts. 
Table 2.4 Knowledge transfer channels and data sources

\begin{tabular}{|c|c|c|}
\hline 1 & 2 & 3 \\
\hline Open science (informal) & Contractual (formal) & IP mediated (formal) \\
\hline $\begin{array}{l}\text { Training of firm staff by } \\
\text { institutions, placement } \\
\text { of postgraduates in } \\
\text { a firm for an internship }\end{array}$ & $\begin{array}{l}\text { Problem solving/ } \\
\text { consultancy with } \\
\text { academics }^{1}\end{array}$ & $\begin{array}{l}\text { Licensing of institutions' } \\
\text { IP (patents, copyright, } \\
\text { industrial designs, } \\
\text { plant breeder's rights, } \\
\text { knowhow, etc.) }\end{array}$ \\
\hline $\begin{array}{l}\text { Hiring university } \\
\text { graduates }\end{array}$ & $\begin{array}{l}\text { Research contracts } \\
\text { (research supported by } \\
\text { financial or in-kind } \\
\text { contributions from } \\
\text { government or } \\
\text { industry) }\end{array}$ & $\begin{array}{l}\text { Spinoffs/startups using } \\
\text { the institute's IP }\end{array}$ \\
\hline $\begin{array}{l}\text { Attending conferences or } \\
\text { workshops }\end{array}$ & $\begin{array}{l}\text { Collaborative R\&D } \\
\text { projects (joint funding } \\
\text { and participation by } \\
\text { the public organization } \\
\text { and government or } \\
\text { industry) }\end{array}$ & $\begin{array}{l}\text { Joint ventures using the } \\
\text { institute's IP }\end{array}$ \\
\hline \multicolumn{3}{|l|}{$\begin{array}{l}\text { Reading academic } \\
\text { literature }\end{array}$} \\
\hline \multicolumn{3}{|l|}{ Personal contacts } \\
\hline \multicolumn{3}{|l|}{$\begin{array}{l}\text { Access to advanced } \\
\text { facilities or equipment }\end{array}$} \\
\hline \multicolumn{3}{|l|}{ Data sources } \\
\hline $\begin{array}{l}\text { Surveys of firms or } \\
\text { academics }\end{array}$ & $\begin{array}{l}\text { Surveys of academics, } \\
\text { firms, or KTOs }{ }^{1}\end{array}$ & $\begin{array}{l}\text { Surveys of KTOs, firms, } \\
\text { or public data sources }\end{array}$ \\
\hline
\end{tabular}

Source: Cohen et al. (2002); Cosh et al. (2006); Ramos-Vielba and FernándezEsquinas (2012); Tartari and Breschi (2012)

${ }^{1}$ KTOs may be unaware of many private consultancies between academics and firms, particularly if academics are not legally required to report private consultancies to their institution.

science, followed by contracts for the creation of new knowledge (Cohen et al. 2002; Siegel et al. 2003; Cosh et al. 2006; D'Este and Patel 2007; De Fuentes and Dutrénit 2012; Hughes and Kitson 2012; Grimpe and Hussinger 2013; Freitas et al. 2013; Okamuro and Nishimura 2013; 
Dutrénit and Arza 2015; Kafouros et al. 2015; Kruss et al. 2015; Schiller and Lee 2015). This is also partly reflected in the source of knowledge transfer income. In the United Kingdom, contract and collaborative research account for the majority of university income from knowledge transfer, with IP income accounting for only 2 percent to 4 percent of the total (Cosh et al. 2006; Zhang et al. 2016).

\subsubsection{Basic Metrics of Knowledge Transfer via Licensing}

Metrics include statistics and indicators. Relevant statistics for knowledge transfer include count data such as number of patent applications and the total amount of license income earned. Indicators standardize a statistic, for instance by providing the number of patent applications per 1,000 research academics in the sciences or the amount of license income earned per EUR 1 million in research expenditures. Both statistics and indicators need to refer to a defined time period such as one calendar year.

Indicators are essential for benchmarking performance. Using statistics to compare the number of invention disclosures among a group of universities would be seriously misleading if the group included universities with large differences in the number of academic staff or in the types of discipline. A university that focuses on law and the humanities is likely to have far fewer opportunities for consulting contracts than one that focuses on science, technology, and medicine.

There are three main reasons for collecting knowledge transfer metrics for licensing:

1. to benchmark knowledge transfer activities, for instance to permit comparisons in performance within an institution, across institutions, or over time;

2. for use in analyses to identify the factors that either support or hinder knowledge transfer; and

3. to inform policy, such as determining the effect of a change in policy on knowledge transfer outcomes.

These three reasons are linked because research on the factors that support knowledge transfer can use benchmarking data as an output measure, for example, in a study of the factors that increase the number of patents or the amount of license revenue. Plus, research on "what works" can be of value in developing or improving policies to support knowledge transfer. 


\subsection{Collecting Knowledge Transfer Metrics for Licensing}

The most common source of basic metrics is surveys of KTOs on activities that are part of the IP licensing model. These metrics are available on an intermittent or annual basis in many high-income countries, including the member states of the European Union, the U.S., Canada, Australia, and New Zealand. Most surveys of KTOs follow the definitions and standards set by the AUTM for its surveys of KTOs in the U.S. and Canada. The AUTM has been collecting metrics since the early 1990s.

Table 2.5 summarizes seven basic metrics from KTO surveys: the number of (1) invention disclosures, (2) patent applications, (3) patent grants, (4) research agreements, (5) license agreements, (6) startup establishments, and (7) total license revenue earned. None of these metrics is a direct measure of commercialization. Invention disclosures refer to an

Table 2.5 Basic metrics from KTO surveys

\begin{tabular}{|c|c|c|}
\hline & Statistic & Definition $^{1}$ \\
\hline 1 & $\begin{array}{l}\text { Number of invention } \\
\text { disclosures }\end{array}$ & $\begin{array}{l}\text { Descriptions of inventions or discoveries } \\
\text { that are evaluated by the KTO staff or } \\
\text { other technology experts to assess their } \\
\text { commercial application }\end{array}$ \\
\hline 2 & Number of patent applications & $\begin{array}{l}\text { New priority patent applications. Exclude } \\
\text { double-counting, such as a patent } \\
\text { application for the same invention in } \\
\text { more than one patent jurisdiction }\end{array}$ \\
\hline 3 & Number of patents granted & $\begin{array}{l}\text { Technically unique patents granted. } \\
\text { Count a patent grant for the same } \\
\text { invention in two or more countries as } \\
\text { one technically unique patent. If } \\
\text { a technically unique patent grant has } \\
\text { been counted in a previous year, it may } \\
\text { not be counted again }\end{array}$ \\
\hline 4 & $\begin{array}{l}\text { Number of research } \\
\text { agreements }\end{array}$ & $\begin{array}{l}\text { All contracts where a firm funds the } \\
\text { university or public research institute to } \\
\text { perform research on behalf of the firm, } \\
\text { with the results usually provided to the } \\
\text { firm. Include collaborative agreements }\end{array}$ \\
\hline
\end{tabular}


Table 2.5 (cont.)

\begin{tabular}{|c|c|c|}
\hline & Statistic & Definition \\
\hline & & $\begin{array}{l}\text { where both partners provide funding } \\
\text { and share the results. Exclude cases } \\
\text { where the firm funds a research chair or } \\
\text { other research of no expected } \\
\text { commercial value to the firm }\end{array}$ \\
\hline 5 & Number of licenses executed & $\begin{array}{l}\text { Include all licenses, options and } \\
\text { assignments (LOAs) for all types of IP } \\
\text { copyright, knowhow, patents, etc. } \\
\text { Count multiple (identical) licenses with } \\
\text { a value of less than EUR } 500 \text { each as one } \\
\text { license. A license grants the right to use } \\
\text { IP in a defined field of use or territory. } \\
\text { An option grants the potential licensee } \\
\text { a time period to evaluate the technology } \\
\text { and negotiate the terms of a license. An } \\
\text { assignment transfers all or part of the } \\
\text { right to IP to the licensee }\end{array}$ \\
\hline 6 & Number of startups ${ }^{2}$ & $\begin{array}{l}\text { A new company expressly established to } \\
\text { develop or exploit IP or knowhow } \\
\text { created by the university/PRO and with } \\
\text { a formal contractual relationship for } \\
\text { this IP or knowhow, such as a license or } \\
\text { equity agreement. Include, but do not } \\
\text { limit to, spinoffs established by the } \\
\text { institution's staff. Exclude startups that } \\
\text { do not sign a formal agreement on } \\
\text { developing IP or knowhow created by } \\
\text { the institution }\end{array}$ \\
\hline 7 & Total license revenue earned & $\begin{array}{l}\text { Total income from all types of knowhow } \\
\text { and IP (patents, copyright, designs, } \\
\text { material transfer agreements, } \\
\text { confidentiality agreements, plant } \\
\text { breeders' rights, etc.) before } \\
\text { disbursement to the inventor or other } \\
\text { parties. Include license issue fees, } \\
\text { annual fees, option fees, and milestone, } \\
\text { termination and cash-in payments. }\end{array}$ \\
\hline
\end{tabular}


Table 2.5 (cont.)

\begin{tabular}{ll}
\hline \hline Statistic & Definition \\
\hline & $\begin{array}{l}\text { Exclude license income forwarded to } \\
\text { other institutions than those served by } \\
\text { the KTO or to companies }\end{array}$ \\
\hline \hline
\end{tabular}

Source: Authors

${ }^{1}$ The definitions follow those used by the AUTM, but have been adapted for simplicity and for use in countries other than the U.S. See European Commission (2009).

${ }^{2}$ Startups include both spinoffs established by university/public research institute staff using the institution's IP and new companies that take a license to commercialize an institution's IP, but do not include its staff.

unknown potential for commercialization, with many never patented or licensed. Patent grants can remain unlicensed, research agreements can result in no new knowledge of commercial value, and licenses may never lead to commercialized processes or products.

None of these seven metrics measures the successful commercialization of IP produced in universities and public research institutes - all are metrics of inputs into potential commercialization. ${ }^{11}$ The first three metrics (invention disclosures, patent applications, and patent grants) are the furthest from commercialization, but invention disclosures are the first step in an IP-mediated commercialization process. The next step, if an evaluation of the invention disclosure results in a decision that there is commercial potential, is to file a patent application or seek other forms of IP if a patent is not suitable.

The two metrics that are closest to commercialization are the number of startups established and license revenue earned. Licenses indicate that a firm has an interest in commercializing the licensed IP, but many licenses, particularly for generic technologies or research tools, fail to lead to the commercialization of new goods, services or processes. ${ }^{12}$ Similarly, research agreements and startups indicate that a firm is

${ }^{11}$ Kochenkova et al. (2015) note that there is very little research on the effect of policies to support knowledge transfer on commercialization outcomes, with most studies focusing on intermediate outcomes such as patent counts.

12 An example is the Cohen-Boyer patents, which covered a basic research technique that almost all firms active in biotechnology needed to license. Some of these firms were startups that never produced a commercial product. 
interested in the commercial potential of knowledge produced by institutions, but we do not know if the research agreement produced useful research results or if the startup was able to commercialize a product or process.

Identifying the commercialization of new knowledge produced by universities and public research institutes requires the ability to identify licenses that earn running royalties (royalties earned on and tied to the sales of products) or the ability to follow startups over time and determine if they commercialized IP obtained from the institution. Recent AUTM surveys have collected data on running royalties (AUTM 2015b) and "net product sales," which includes sales from IP licensed to startups. ${ }^{13}$ European KTOs have begun to track outcomes for startups, but there is not yet agreement on the types of outcome that should be collected over time (Arundel et al. 2013).

\subsubsection{Supplementary Metrics from KTOs}

In addition to the basic metrics covered in Table 2.5, KTO surveys can provide a variety of supplementary indicators of relevance to licensing. Table 2.6 lists supplementary indicators and their relevance to policy. The list is limited to indicators of value for benchmarking performance, the development of policies to support knowledge transfer and the ability of KTOs to efficiently manage patent portfolios.

A 2009 review of KTO metrics in Europe and the U.S. found that only two of the supplementary metrics listed in Table 2.6 were collected in most countries: the number of valid patents in the patent portfolio (item 3) and licenses by firm size (item 5). Data on exclusive and nonexclusive licenses were available only for the U.S. and Canada via the AUTM survey and in a Swiss survey (European Commission 2009), but questions on exclusive and nonexclusive patents have been included in later European surveys (Arundel et al. 2013).

Table 2.6 includes counts for PCT patent applications. These can be filed instead of a national application and lead to patent protection in up to 140 countries. The PCT is usually only used when the applicant wishes to acquire a patent in one or more nondomestic countries. In most countries, its use therefore indicates a higher-quality patent with good commercial potential.

${ }^{13}$ Question S-3, AUTM (2015b). 
Table 2.6 Supplementary metrics from KTO surveys ${ }^{1}$
Statistic
Policy use

Supplementary metrics for patents

1 Domestic patent applications or grants

These can be "entry-level" patents with limited commercial application, particularly if domestic patenting costs and/or the bar for a patent are low. A continuing high share of domestic patents out of total patents over time could indicate low commercialization potential or that too many low-value inventions are patented

2 Foreign patent applications or grants (USPTO, EPO, PCT, etc.)

$3 \quad$ Number of granted patents in the current portfolio that are valid (patent renewal fees have been paid)

\section{Supplementary metrics for licensing}

4 Number of patents in the current portfolio that have ever been licensed

5 Licenses by licensee type: startups, SMEs, regional firms, etc.

$6 \quad$ Exclusive and nonexclusive licenses
Foreign patents in large markets such as the European Union or the U.S. indicate high commercialization potential. An increase in the share of foreign patents out of all patents indicates an improvement in inventive capabilities/commercialization opportunities over time

Combined with the next indicator, data on the size of the patent portfolio can be used to determine the share of patents that have ever been patented. This should increase over time as the KTO gains greater experience

The share should increase over time.

A stable or declining share could indicate that the KTO is applying for a patent for too many invention disclosures

The share of licenses to regional firms (SMEs or startups) is of interest if the government has a policy of encouraging local development. The disadvantage is that focusing on regional IP partners can reduce license revenue ${ }^{2}$

Nonexclusive licenses are income earners for universities/public research institutes, but are not necessary (no IP 
Table 2.6 (cont.)

\begin{tabular}{|c|c|c|}
\hline & Statistic & Policy use \\
\hline & & $\begin{array}{l}\text { is required) if the policy goal is to get as } \\
\text { many firms as possible to take up the } \\
\text { knowledge covered by the license }\end{array}$ \\
\hline 7 & $\begin{array}{l}\text { Licenses by type of IP (patents, } \\
\text { knowhow, copyright, etc.) }\end{array}$ & $\begin{array}{l}\text { Patentability is limited to specific types of } \\
\text { knowledge, with other types of IP } \\
\text { required for other types of knowledge. } \\
\text { Data on other types of IP used in } \\
\text { licensing can identify if the license } \\
\text { portfolio is commensurate with the } \\
\text { types of knowledge produced by the } \\
\text { university/public research institute }\end{array}$ \\
\hline 8 & $\begin{array}{l}\text { Licenses by technology field } \\
\text { (software, biomedical, } \\
\text { nanotechnology, etc.) }\end{array}$ & $\begin{array}{l}\text { Specific technology fields can dominate } \\
\text { licensing and license revenue (in } \\
\text { Europe, it is the biotechnology/medical } \\
\text { fields). Good benchmarking across } \\
\text { universities and public research } \\
\text { institutes should therefore be based on } \\
\text { comparing metrics by technology field } \\
\text { to compare like with like. Licensing by } \\
\text { field can also be an indicator for } \\
\text { decisions on research investments }\end{array}$ \\
\hline \multicolumn{3}{|c|}{ Supplementary revenue indicators } \\
\hline 9 & $\begin{array}{l}\text { License revenue from running } \\
\text { royalties/sales of products } \\
\text { based on university/public } \\
\text { research institute IP }\end{array}$ & $\begin{array}{l}\text { Measures of commercialization of } \\
\text { knowledge produced by universities/ } \\
\text { public research institutes }\end{array}$ \\
\hline \multicolumn{3}{|c|}{ Supplementary revenue indicators } \\
\hline 10 & $\begin{array}{l}\text { Startups that have } \\
\text { commercialized university/ } \\
\text { public research institute IP }\end{array}$ & $\begin{array}{l}\text { Measure of commercialization of } \\
\text { knowledge produced by universities/ } \\
\text { public research institutes }\end{array}$ \\
\hline 11 & $\begin{array}{l}\text { Startup sales of products from } \\
\text { university/public research } \\
\text { institute IP, employment in } \\
\text { startups with such sales }\end{array}$ & $\begin{array}{l}\text { Measure of commercialization of } \\
\text { knowledge produced by universities/ } \\
\text { public research institutes }\end{array}$ \\
\hline
\end{tabular}

\footnotetext{
Source: Authors

${ }^{1}$ For brevity, this table does not include foreign research agreements or licenses.

${ }^{2}$ Belenzon and Schankerman (2009) find that universities with strong local development objectives generate less license income but have more licenses to local startups.
} 
Standardized Indicators

The metrics in Tables 2.5 and 2.6 should be standardized for both internal and international comparisons. For instance, combining the number of current patents that have been licensed with the total number of valid patents in the university/public research institute's patent portfolio produces an indicator for the share of licensed patents. Many of the metrics can be standardized by calculating the rate per 1,000 academic staff or per USD 1 million in purchasing power parities for research expenditures. ${ }^{14}$ Table 2.7 describes these two standardization variables.

Collecting data on research expenditures is necessary in order to compare results with the U.S., as the AUTM does not collect data on the number of academics. Research expenditures are influenced by differences in purchasing power parities (PPP) in different countries. It is a simple matter to use PPP currency conversions, but PPPs are calculated for all economic costs, not just for research costs.

For international comparisons other than with the U.S., there are advantages in using the number of academics rather than research

Table 2.7 Variables for standardizing knowledge transfer office (KTO) metrics

\begin{tabular}{|c|c|c|}
\hline & Statistic & Policy use \\
\hline 1 & $\begin{array}{l}\text { Total number of academic staff } \\
\text { at a public research } \\
\text { organizations active in fields } \\
\text { with a potential for } \\
\text { commercialization }\end{array}$ & $\begin{array}{l}\text { All basic metrics and most of the } \\
\text { supplementary metrics can be } \\
\text { standardized per } 1,000 \text { academic staff. } \\
\text { Standardization per } 1,000 \text { academics is } \\
\text { less relevant for the supplementary } \\
\text { licensing metrics }\end{array}$ \\
\hline 2 & $\begin{array}{l}\text { Total research expenditures in } \\
\text { fields with a potential for } \\
\text { commercialization }\end{array}$ & $\begin{array}{l}\text { As above, but this information is } \\
\text { necessary to compute standardized } \\
\text { metrics for comparison with the AUTM } \\
\text { surveys for the U.S. and is also required } \\
\text { to calculate the license income share of } \\
\text { total research expenditures }\end{array}$ \\
\hline
\end{tabular}

14 Arundel and Bordoy (2010) explore the possibilities and difficulties of developing internationally comparable output indicators for the commercialization of public science. 
expenditures to produce standardized indicators. The number of academic staff in full-time equivalents (FTEs) is possibly more comparable across studies. National differences per 1,000 academics can also be a useful (albeit not an ideal) indicator of academic performance. An alternative is to standardize by the number of peer-reviewed publications (or a quality-adjusted publication measure) per 1,000 academics. Publication counts are positively correlated with patent applications (Van Looy et al. 2011; Berbegal-Mirabent and Sabate 2015).

Metrics for the Characteristics of the KTO and its Institution

For econometric research, it is important to collect control variables on the characteristics of the KTO itself and the institution to which it is responsible. Relevant KTO variables include its age and number of staff and, if possible, the area of expertise of KTO staff and the KTO budget. The KTO's age is particularly important to obtain because it has a significant effect on many knowledge transfer outcomes, due to a positive relationship between KTO age and institutional experience and knowledge transfer activities (Friedman and Silberman 2003; Conti and Gaule 2011; Berbegal-Mirabent and Sabate 2015).

Data should also be collected on several characteristics of the public research institutes and universities that can influence knowledge transfer activities, including:

- the location of the institution in a dynamic region near innovative firms, venture capital, etc.;

- the size and type of the institution: private universities with a commercial orientation can be more active than public universities;

- the portfolio of disciplines, some of which are more prone to knowledge transfer, such as biomedical research;

- the research quality of the institution, its reputation and network; and

- the extent of existing collaboration between the institution and firms.

\subsection{Conclusions}

This chapter describes the different channels that are used by universities, public research institutes, and firms to transfer knowledge between them and the role of policies and institutional practices in supporting knowledge transfer. The chapter largely focuses on the IP licensing model, due to extensive academic research on this channel and data availability, but 
it is essential for a full understanding of knowledge transfer to also evaluate the role of informal and contractual knowledge transfer channels, as summarized in Table 2.4. Several of the country studies in this book take a more holistic perspective by evaluating the role of each channel and how these channels have changed over time in response to policy changes or economic development.

The collection of metrics on knowledge transfer via licensing is essential for benchmarking, identifying the factors that support or hinder knowledge transfer, and to inform policy. There are seven basic metrics that all countries should collect on the IP licensing model, plus supplementary metrics of relevance to specific policy issues, such as if licensing is benefiting domestic firms or the efficiency of IP use, as measured by the share of IP that is licensed. Additional metrics that would support a holistic perspective on knowledge transfer are discussed in Chapter 12.

\section{References}

Abreu, M. and V. Grenevich (2013). "The nature of academic entrepreneurship in the UK: widening the focus on E activities." Research Policy, 42(2), 408-22.

Albuquerque, E., W. Suzigan, G. Kruss, and K. Lee (eds.) (2015). Developing National Systems of Innovation: University-Industry Interactions in the Global South. Cheltenham: Edward Elgar.

Alexy, O., P. Criscuolo, and A. Salter (2009). "Does IP strategy have to cripple open innovation?” MIT Sloan Management Review, October 1.

Arora, A., W. M. Cohen, and J. P. Walsh (2016). "The acquisition and commercialization of invention in American manufacturing: incidence and impact." Research Policy, 45(6), 1113-28.

Arundel, A., F. Barjak, N. Es-Sakdi, F. Barjak, P. Perrett, O. Samuel, and S. Lilischkis (2013). Knowledge Transfer Study 2010-2012: Final Report. Luxembourg: Publications Office of the European Union.

Arundel, A. and C. Bordoy (2010). Developing Internationally Comparable Indicators for the Commercialization of Publicly-funded Research (UNU-MERIT Working Paper Series, 075). Maastricht: United Nations University - Maastricht Economic and Social Research Institute on Innovation and Technology (MERIT).

AUTM (2015a). 2014 Licensing Survey: Instructions and Definitions. www .autm.net/AUTMMain/media/Resources/Documents/AUTM_FY2014_ Licensing_Survey_Instructions_Definitions.pdf.

AUTM (2015b). 2014 Licensing Activity Survey Questionnaire. www.autm.net /AUTMMain/media/Resources/Documents/AUTM_FY2014_Licensing_ Survey_Questionnaire.pdf. 
Azoulay, P., W. Ding, and T. Stuart (2009). "The impact of academic patenting on the rate, quality and direction of (public) research output." Journal of Industrial Economics, 57(4), 637-76.

Barjak, F., N. Es-Sadki, and A. Arundel (2015). "The effectiveness of policies for formal knowledge transfer from European universities and public research institutes to firms." Research Evaluation, 24, 4-18.

Belenzon, S. and M. Schankerman (2009). "University knowledge transfer: private ownership, incentives and local development objectives." Journal of Law and Economics, 52, 111-44.

Berbegal-Mirabent, J. and F. Sabate (2015). "Balancing basic and applied research outputs: a study of the trade-offs between publishing and patenting." Technology Analysis \& Strategic Management, 27, 1143-58.

Boettiger, S. and A. B. Bennett (2006). "The Bayh-Dole Act: Implications for developing countries." IDEA: The Intellectual Property Law Review, 46(2), 259-79.

Calderón-Martínez, M. G. and J. García-Quevedo (2013). “Knowledge transfer and university patents in Mexico." Academia Revista Latinoamericana de Administración, 26, 33-60.

Campbell, E. G., B. R. Clarridge, M. Gokhale, L. Birenbaum, S. Hilgartner, N. A. Holtzman, and D. Blumenthal (2002). "Data withholding in academic genetics: Evidence from a national survey." Journal of the American Medical Association, 287(4), 473-80.

Campbell, E. G., J. S. Weissman, N. Causino, and D. Blumenthal (2000). "Data withholding in academic medicine: characteristics of faculty denied access to research results and biomaterials.” Research Policy, 29(2), 303-31.

Clemente, F.-P. (2006). "The impact of stronger intellectual property rights on science and technology in developing countries." Research Policy, 35(6), 808-24.

Cohen, W., R. Nelson, and J. Walsh (2002). "Links and impacts: The influence of public research on industrial R\&D.” Management Science, 48, 1-23.

Conti, A. and P. Gaule (2011). "Is the US outperforming Europe in university technology licensing? A new perspective on the European paradox." Research Policy, 40(1), 123-35.

Cosh, A., A. Hughes, and R. K Lester. (2006). UK plc: Just How Innovative Are We? (Industrial Performance Centre Massachusetts Institute of Technology Working Paper Series). Cambridge and Cambridge, MA: MIT Institute.

Curi, C., C. Daraio, and P. Llerena (2012). "University technology transfer: How (in)efficient are French universities?" Cambridge Journal of Economics, 36(3), 629-54.

Czarnitzki, D., T. Doherr, K. Hussinger, P. Schliessler, and A.A. Toole (2016). "Knowledge creates markets: The influence of entrepreneurial support and 
patent rights on academic entrepreneurship." European Economic Review, 86, 131-46.

Czarnitzki, D., W. Glänzel, and K. Hussinger (2009). "Heterogeneity of patenting activity and its implications for scientific research." Research Policy 38(1), 26-34.

D'Este, P. and P. Patel (2007). "University-industry linkages in the UK: What are the factors underlying the variety of interactions with industry?" Research Policy, 36(9), 1295-313.

De Fuentes, C. and G. Dutrénit (2012). "Best channels of academia-industry interaction for long-term benefit.” Research Policy, 41(9), 1666-82.

Debackere, K. and R. Veugelers (2005). “The role of academic technology transfer organizations in improving industry-science links." Research Policy, 34(3), 321-42.

Di Gregorio, D. and S. Shane (2003). "Why do some universities generate more start-ups than others?” Research Policy, 32(2), 209-27.

Dutrénit, G. and V. Arza (2015). "Features of interactions between public research institutes and industry in Latin America: The perspective of researchers and firms." In E. Albuquerque, W. Suzigan, G. Kruss, and K. Lee (eds.), Developing National Systems of Innovation: University-Industry Interactions in the Global South. Cheltenham: Edward Elgar.

Eisenberg, R. (1989). "Patents and the progress of science: exclusive rights and experimental use." University of Chicago Law Review, 56, 1017-55.

Engel, N. (2008). "University patenting and its effects: an assessment for developing countries.” In C. S. Krishna (ed.), Technology Transfer: Intellectual Property Rights. Hyderabad: Amicus Books/Icfai University Press.

European Commission (2009). Metrics for Knowledge Transfer from Public research institutes in Europe. Brussels: European Commission.

Fabrizio, K. R. and A. Di Minin (2008). "Commercializing the laboratory: Faculty patenting and the open science environment." Research Policy, 37(5), 914-31.

Fisch, C. O., J. H. Block, and P. G. Sandner (2016). "Chinese university patents: Quantity, quality, and the role of subsidy programs." Journal of Technology Transfer, 41, 60-84.

Fisch, C. O., T. M. Hassel, P. G. Sandner, and J. H. Block (2015). "University patenting: A comparison of 300 leading universities worldwide." Journal of Technology Transfer, 40, 318-45.

Foray, D. and F. Lissoni (2010). "University research and public-private interaction.” In B. H. Hall and N. Rosenberg (eds.), Handbook of the Economics of Innovation (Vol. 1). Amsterdam: North Holland.

Freitas, I. M. B., A. Geuna, and F. Rossi (2013). "Finding the right partners: Institutional and personal modes of governance of university-industry interactions." Research Policy, 42(1), 50-62. 
Friedman, J. and J. Silberman (2003). "University technology transfer: Do incentives, management, and location matter?” Journal of Technology Transfer, 28, 17-30.

Grimaldi, R., M. Kenney, D. S. Siegel, and M. Wright (2011). “30 years after Bayh-Dole: Reassessing academic entrepreneurship.” Research Policy, 40(8), 1045-57.

Grimpe, C. and K. Hussinger (2013). "Formal and informal knowledge and technology transfer from academia to industry: Complementarity effects and innovation performance." Industry and Innovation, 20, 683-700.

Hayer, C. S. (2016). "A trajectory of early-stage spinoff success: The role of knowledge intermediaries within an entrepreneurial university ecosystem." Small Business Economics, 47, 633-56.

Heller, M. and R. Eisenberg (1998). "Can patents deter innovation? The anticommons in biomedical research." Science, 280, 698-701.

Hewitt-Dundas, N. (2012). "Research intensity and knowledge transfer activity in UK universities.” Research Policy, 41(2), 262-75.

Hughes, A. and M. Kitson (2012). "Pathways to impact and the strategic role of universities: New evidence on the breadth and depth of university knowledge exchange in the UK and the factors constraining its development." Cambridge Journal of Economics, 36, 723-50.

Hussain, W. M. H. W., M. N. A. Rahman, Z. A. Zainol, and N. I. Yaakub (2014). "Mechanism and government initiatives of promoting innovation and commercialization of university invention." Pertanika Journal of Social Sciences and Humanities, 22, 131-48.

Kafouros, M., C. Q. Wang., P. Piperopoulos, and M. S. Zhang (2015). “Academic collaborations and firm innovation performance in China: The role of region-specific institutions," Research Policy, 44(3), 803-17.

Kearnes, M. and M. Wienroth (2011). "Tools of the trade: UK research intermediaries and the politics of impacts." Minerva, 49, 153-74.

Kenney, M. and D. Patton (2011). "Does inventor ownership encourage university research-derived entrepreneurship? A six university comparison," Research Policy, 40(8), 1100-12.

Kochenkova, A., R. Grimaldi, and F. Munari (2015). "Public policy measures in support of knowledge transfer activities: A review of academic literature." Journal of Technology Transfer, 41, 407-29.

Kruss, G., J. O. Adeoti, and D. Nabudere (2015). "Bracing for change: Making universities and firms partners for innovation in sub-Saharan Africa." In E. Albuquerque, W. Suzigan, G. Kruss, and K. Lee (eds.), Developing National Systems of Innovation: University-Industry Interactions in the Global South. Cheltenham: Edward Elgar.

Link, A. N., D. S. Siegel, and B. Bozeman (2007). "An empirical analysis of the propensity of academics to engage in informal university technology transfer." Industrial and Corporate Change, 16(4), 641-55. 
Litan, R. E., L. Mitchell, and E. J. Reedy (2008). "Commercializing university innovations: Alternative approaches." In A. B. Jaffe, J. Lerner, and S. Stern (eds.), Innovation Policy and the Economy (Vol. 8). Cambridge, MA: MIT Press.

Montobbio, F. (2009). "Intellectual property rights and knowledge transfer from public research to industry in the US and Europe: Which lessons for innovation systems in developing countries?" In The Economics of Intellectual Property: Suggestions for Further Research in Developing Countries and Countries with Economies in Transition. Geneva: World Intellectual Property Organization.

Muscio, A. and A. Pozzali (2013). "The effects of cognitive distance in university-industry collaborations: Some evidence from Italian universities." Journal of Technology Transfer, 38(4), 486-508.

OECD (2003). Turning Science into Business - Patenting and Licensing at Public research institutes. Paris: Organisation for Economic Co-operation and Development.

Okamuro, H. and J. Nishimura (2013). "Impact of university intellectual property policy on the performance of university-industry research collaboration." Journal of Technology Transfer, 38(3), 273-301.

Owen-Smith, J. and W. W. Powell (2003). "The expanding role of university patenting in the life sciences: Assessing the importance of experience and connectivity." Research Policy, 32(9), 1695-711.

Ramos-Vielba, I. and M. Fernández-Esquinas (2012). "Beneath the tip of the iceberg: Exploring the multiple forms of university-industry linkages." Higher Education, 64, 237-65.

Ranga, M., S. Temel, I. M. Ar, R. B. Yesilay, and F. V. Sukan (2016). "Building technology transfer capacity in Turkish universities: A critical analysis." European Journal of Education, 51, 90-106.

Rosenberg, N. and R. R. Nelson (1994). "American universities and technical advance in industry." Research Policy, 23(3), 323-48.

Rosli, A. and F. Rossi (2014). Explaining the Gap between Policy Aspirations and Implementation: The Case of University Knowledge Transfer Policy in the United Kingdom (CIMR Research Working Paper Series no. 20). London: Birkbeck.

Rothaermel, F. T., S. D. Agung, and L. Jiang (2007). "University entrepreneurship: A taxonomy of the literature." Industrial and Corporate Change, 16(4), 691-791.

Schiller, D. and K. Lee (2015). "Are university-industry links meaningful for catch up? A comparative analysis of five Asian countries." in E. Albuquerque, W. Suzigan, G. Kruss, and K. Lee (eds.), Developing National Systems of Innovation: University-Industry Interactions in the Global South. Cheltenham: Edward Elgar.

Shapiro, M. A. (2012). "Receiving information at Korean and Taiwanese universities (add-on by WIPO, Taiwan, Province of China), industry, and GRIs." Scientometrics, 90, 289-309. 
Siegel, D. S., D. Waldman, and A. Link (2003). "Assessing the impact of organizational practices on the relative productivity of university technology transfer offices: An exploratory study." Research Policy, 32(1), 27-48.

Sigurdson, K., C. M. Sa, and A. Kretz (2015). "Looking for the street light: Limitations of mainstream technology transfer indicators." Science and Public Policy, 42, 632-45.

So, A. D., B. N. Sampat, A. K. Rai, R. Cook-Deegan, J. H. Reichman, R. Weissman, and A. Kapcynski (2008). "Is Bayh-Dole good for developing countries? Lessons from the US experience.” PLoS Biol, 6(10): e262.

Tartari, V. and S. Breschi (2012). "Set them free: Scientists' evaluations of the benefits and costs of university-industry research collaboration." Industrial and Corporate Change, 21, 1117-47.

Thursby, G. and M. C. Thursby (2007). "University licensing." Oxford Review of Economic Policy, 23, 620-39.

Trzmielak, D. M. and G. Małgorzata (2014). "Knowledge and technology transfer barriers - Polish universities' perspectives." Paper presented at the International Conference on Management of Innovation and Technology (ICMIT). Singapore: IEEE.

Van Looy, B., P. Landoni, J. Callaert, B. Van Pottelsberghe, E. Sapsalis, and K. Debackere (2011). "Entrepreneurial effectiveness of European universities: An empirical assessment of antecedents and tradeoffs." Research Policy, 40(4), 553-64.

Van Looy, B., M. Ranga, J. Callaert, K. Debackere, and E. Zimmerman (2004). "Combining entrepreneurial and scientific performance in academia: Towards a compounded and reciprocal Matthew-effect?” Research Policy, 33(3), 425-41.

Veugelers, R. (2016). “The embodiment of knowledge: Universities as engines of growth." Oxford Review of Economic Policy, 32, 615-31.

Wadhwa, V. (2011) “Innovation's golden opportunity." Washington Post: www.washingtonpost.com/national/on-innovations/innovations-goldenopportunity/2011/06/09/AGWrnJOH_story.html?noredirect=on

WIPO (2011). "Harnessing public research for innovation - the role of intellectual property." In World Intellectual Property Report 2011: The Changing Face of Innovation. Geneva: World Intellectual Property Organization (WIPO). www.wipo.int/edocs/pubdocs/en/wipo_pub_944_2011-chapter4.pdf.

$\mathrm{Wu}, \mathrm{W}$. (2009). "Managing and incentivizing research commercialization in Chinese universities.” Journal of Technology Transfer, 35(2), 203-24.

Zhang, Q., N. G. MacKenzie, D. Jones-Evans and R. Huggins (2016). "Leveraging knowledge as a competitive asset? The intensity, performance and structure of universities entrepreneurial knowledge activities at a regional level." Small Business Economics, 47, 657-75. 
Zucker, L. G., M. R. Darby, and M. B. Brewer (1998). "Intellectual human capital and the birth of U.S. biotechnology enterprises." American Economic Review, 88 (1), 290-306.

Zuñiga, P. (2011). The State of Patenting at Research Institutions in Developing Countries: Policy Approaches and Practices (WIPO Economics Research Working Papers No. 4). Geneva: World Intellectual Property Organization. www.wipo.int/edocs/pubdocs/en/wipo_pub_econstat_wp_4.pdf. 